AperTO - Archivio Istituzionale Open Access dell'Università di Torino

\title{
Minorities in Samarkand: A Case Study of the City's Koreans
}

\section{This is the author's manuscript}

Original Citation:

Availability:

This version is available http://hdl.handle.net/2318/102024

since

Terms of use:

Open Access

Anyone can freely access the full text of works made available as "Open Access". Works made available under a Creative Commons license can be used according to the terms and conditions of said license. Use of all other works requires consent of the right holder (author or publisher) if not exempted from copyright protection by the applicable law. 


\title{
Minorities in Samarkand: A Case Study of the City's Koreans*
}

\author{
Marco Buttino
}

Annexation into the Russian Empire transformed the cities of Central Asia. The European presence increased steadily from year to year and with it new city neighborhoods were created, often alongside the old quarters in which the autochthonous population lived. With increased immigration during the Soviet era, the majority of the population in the region's principal cities were either Slavs or Russified minorities and the common language used by all the inhabitants, including the autochthonous ones who continued to use their mother tongue, was Russian. The Soviets saw these changes as part of a process of modernization starting in the cities' European neighborhoods which would spread progressively to the local population.

An important role in this cultural transformation was played by those groups which had moved to the region partly spontaneously, partly because encouraged by the Soviet authorities and partly because forced to resettle there. They were newcomers from the European regions of the USSR as well as from areas with non-Slavic populations. It was held to be essential that the non-Slavic minorities should follow a process of integration and assimilation into the Russian world, becoming part of the modern heart of the cities. Using what in the context may be an imprecise term, we can say that these minorities were expected to become part of the "colonial" society that was grounded in the European neighborhoods of the cities; integration was not expected to take place with the autochthonous peoples.

This study is concerned with the Koreans who were deported to the Samarkand region before the Second World War. It explores the ways in which a deported minority ingeniously adapted to the new environment and was capable of negotiating with the Soviet authorities a respectable position in the local society. Many of them, having made agriculture their strong point, shifted their effort towards becoming part of the Soviet and Russian-speaking world of the city. We will follow the various phases of their integration up to the collapse of the USSR, and then see how new processes of identity construction gained ground in the subsequent period.

Samarkand is a medium-sized city, where the distinctive ways of life characteristic of different city neighborhoods are clearly visible. It is an excellent laboratory for studying the processes of assimilation into Soviet society. We will use documents from the city's archives to investigate the Soviet period, starting from the years

Marco Buttino, Dipartimento di Storia, Università di Torino, via S. Ottavio 20, 10124 Torino, Italy. Email: marco.buttino@unito.it 
immediately preceding the Second World War and until the mid-1980s. As we have no archive material for the last 20 years, the sources for this period will be oral historythe stories told by people I interviewed, speaking about themselves, their families and also about their national community. Those interviewed generally took for granted the fact that they shared the collective fate of their national group. This sense of belonging to a specific group is to some extent a heritage of the past, the result of the deportations, administrative procedures and policies of social promotion and control of the Soviet era, while, as will be shown, it is also the product of new forms of discrimination.

\section{The Koreans Arrive in Uzbekistan and Samarkand}

Between 1937 and 1944 thousands of people from other regions of the USSR poured into Uzbekistan. The Koreans were the first to arrive, deported in 1937 from the Siberian Far East. They were followed by Poles, deported after the partition of Poland in 1939. In the early years of the war other deportees arrived: Crimean Tatars, Meshket Turks, peoples from the northern Caucasus. In addition to these peoples who were officially "punished" because they were felt to be real or potential Nazi collaborators, people evacuated from the European regions of the USSR occupied by the Nazis also arrived in Uzbekistan and in Samarkand.

It can be estimated that during the war years approximately 65,000 people arrived in the Samarkand region, of which at least 12,000 immediately settled in Samarkand. Approximately 5,000 of the latter were deportees while the other 7,000 were evacuees from western regions where invasion was thought to be imminent. In 1939 the city had a population of $139,000 .{ }^{1}$ The impact of the new arrivals was far from negligible, considering that during the war the number of original inhabitants fell as men were sent to the front.

The first wave of deportees, 30,000 Koreans, arrived in Uzbekistan in September 1937. In the months that followed another 75,000 people arrived, of which 9,000 were sent to Samarkand. ${ }^{2}$ Very little was done by way of preparation to receive them. The special commission in charge of receiving the deportees was in fact incapable of handling this tidal wave of arrivals. There was no housing available and makeshift living quarters had to be arranged for them, often in yurts (portable, felt-covered dwellings) and even in chaikonas (tea-houses) transformed into dormitories. This situation persisted at the end of the summer. A particularly bitter winter was awaiting them. Meanwhile, during the winter of 1937/1938, after months of waiting, the first groups of Koreans were sent to kolkhozy (collective farms). Settling them proceeded slowly, and in fact continued throughout 1938 and $1939 .^{3}$

The Koreans were in an ambiguous position: they were not free but neither were they prisoners. Although in practice they enjoyed limited rights, they were not legally defined in the same way as the kulaks deported during collectivization, i.e. 
as spetspereselentsy. Even during the war their status remained ambiguous, while in 1945 they became spetspereselentsy to all intents and purposes and were subject to the severe controls envisaged for all deportees who were part of this category. In 1948 they were issued with internal passports that allowed them to live only in Central Asia. ${ }^{4}$

According to the 1939 census, in the Samarkand region there were 6,373 Koreans living in villages and 2,309 in cities, 1,959 of these in Samarkand. They were but a tiny minority considering that the population of the region's rural areas was $830,000 .^{5}$ Their prevalent employment in agriculture is consistent with the fact that in the Far East most Koreans were farmers. In reality, many who previously had not been farmers found themselves working the land. For example, several families of fishermen were initially employed in fish farming on kolkhozy but then these kolkhozy did not obtain the equipment needed (e.g. nets, boats, fish food) and were forced to close two or three years later. ${ }^{6}$

To start working in agriculture the Koreans needed land and credit to purchase irrigation systems, seed, and farm machinery and to build houses for themselves. They obtained the poorest land, the land that the Uzbek kolkhozy did not use. There was little credit and it arrived late. Building houses also proceeded slowly. As late as 1940 it was recognized that hundreds of houses were still needed and the Uzbek Sovnarkom turned to Moscow to obtain financing to build them. ${ }^{7}$ I could find no evidence of this aid ever having arrived. Moreover, the war was soon to start and the resources of the Soviet state would be earmarked for other purposes.

The living conditions of the Korean deportees were terrible-poverty and illness were rife, and during the first years hundreds of them died from epidemic diseases. In theory the deportees were entitled to compensation for the goods they had had to abandon when leaving the Far East. ${ }^{9}$ Their representatives repeatedly requested this reimbursement but in June 1940 they learned from Moscow that the deportees' rights to compensation were denied since they had already received aid to allow them to settle. ${ }^{10}$

Despite these many difficulties, the Koreans became successful farmers. The reasons for their relative success reside first in their tendency to form all-Korean kolkhozy; second, in the adoption of specialized crop production (rice); and third, on the way they organized work on their kolkhozy. Let us examine these aspects more fully.

At the end of 1937, many Korean farmers were placed on existing kolkhozy, composed mainly of Uzbeks. Sending them to these kolkhozy was the result of the urgent need to find living quarters that would allow the deportees to face the winter cold. However, settlement on Uzbek kolkhozy did not work well. The Koreans' distinct way of life and the lack of a common language made it difficult for people in the kishlaks (rural settlements of native people) to work together. Many of the Koreans knew Russian as they had been living in the Far East, but in the kishlaks it was Uzbek or Tajiki that was spoken. The difficulties of everyday life during these first years on the kolkhozy were described by Koreans I interviewed. Some of them proudly asserted 
that Koreans are hard working and well organized but are not willing to be told what to do by Uzbeks. ${ }^{11}$

In the spring of 1938 the first all-Korean kolkhozy were set up and by November half the deportees in the Samarkand region had been settled there. ${ }^{12}$ At the start of 1940, two-thirds of them were living and working on all-Korean kolkhozy and only one-third on Uzbek kolkhozy. ${ }^{13}$ Local political power was favorable to allotting separate land to Korean families that had initially been placed with Uzbeks. Korean kolkhozy were located near those of the Uzbeks, on land the Uzbeks were not working and did not expect to work in the near future. The Korean families transferred onto them found themselves without dwellings, living on poor-quality land on which it was impossible to grow cotton. ${ }^{14}$ They began to till virgin land, swampland and rocky river banks. However, many Koreans did not see the move as negative and were attracted to these segregated kolkhozy because they could organize work independently and differently than in Uzbek kolkhozy. The main difference, obvious to everyone, was that they did not produce cotton. The Koreans asked to be allowed to devote themselves principally to their traditional crop, rice.

A good example of what was happening is a petition sent by 45 Korean families to Uzbekistan's Commissar of Agriculture in October 1940. The representatives of the families are aware that by addressing the Commissar directly, and therefore the government of the Uzbek Republic, they are committing a serious infraction, for they are bypassing many expected intermediate steps. They explain that they have tried the intermediate routes but received no answer to their requests. They identify themselves as farmers on the "Lenin" artel' in the Samarkand region (the artel' had a lower level of socialization of land and work than a kolkhozy; we will return to this aspect below). They write that when they joined the "Lenin," in 1938, cotton was being grown in the fields by Uzbek and Russian farmers with excellent results, far beyond the objectives established. The output worsened decidedly since the Koreans started to work there. The signatories of the petition argue that Koreans were not skilled in cotton production and therefore their productivity was low. In the Far East they had been rice farmers and fishermen and did not know how to work cotton fields. With the drop in production, from one year to the next there was also a decrease in the pay the farmers received. Their financial situation became difficult and many had left the "Lenin" to find work on other kolkhozy where possibly(?) cotton was not the sole crop. For these reasons the Korean farmers who had stayed on the "Lenin" kolkhoz asked the authorities for permission to raise different crops. ${ }^{15}$

Despite pressure from Tashkent and Moscow to increase cotton production in Uzbekistan, ${ }^{16}$ the Koreans' request to devote themselves principally to growing rice and, marginally, other food crops was accepted. Their previous requests, submitted over a period of several years, had all been turned down. From this point on, the Koreans increasingly specialized in cultivating rice and Uzbek farmers in growing cotton. In this way, plov, Uzbek farmers' traditional dish, came to be made with rice grown by Koreans. It is likely that their success depended less on the strength 
of their negotiating position vis-à-vis the Soviet authorities and more on the increased need for agricultural produce that was felt throughout the USSR during the Second World War. In Moscow, the party, which still distrusted the Koreans, decided that instead of drafting them into the army they would be used in farming. A similar decision was taken regarding Germans from the Volga, while the peoples of the northern Caucasus were enlisted at the beginning of the war but were then dismissed on the grounds that it was nearly impossible to get them to respect military discipline. ${ }^{17}$

The Koreans stubbornly insisted on specializing in rice not only because this was part of their traditional way of life. They had another, more important reason: rice growing requires particularly intense work, which the Koreans were accustomed to carrying out with the cooperation of all family members. Obviously, given this, the authorities had to allow them to organize themselves with a fair degree of autonomy. The rice-growing kolkhozy came to represent the principal point of aggregation for the Korean diaspora in the first years after deportation. Moves towards these kolkhozy and between kolkhozy in different regions allowed the Koreans to rebuild their networks of relationships inside families that had been torn apart by the deportation. In the Far East, when they were forced to board the trains taking them to Central Asia, families had lost some of their members. Ethnically mixed families were broken up as the Soviets deported only the Korean members, therefore separating husbands and wives and parents from children. Other entirely Korean families had been separated during deportation merely by chance: members of a family who were not in the same place when the deportation order was issued were placed on different trains and arrived at different destinations. Soviet bureaucratic criteria worked independently from the ties which existed between the people being transported. However, once they arrived in Central Asia, the Koreans, although not always successfully, actively sought to find out what had become of their kin and worked hard to obtain the right to be with them again. ${ }^{18}$ There were also large-scale moves of Koreans from Kazakhstan to Uzbekistan: the Koreans were attracted to Uzbekistan by the possibility of joining their families and devoting themselves to growing rice. ${ }^{19}$ Their equivocal position, in which they were not prisoners, although they were not free, left space for these movements from one region to another.

Not all the Koreans were immediately sent to rural areas: about one-fifth of the deportees in the oblast of Samarkand (a small group of approximately 2,000 people) were sent to its capital city. They wound up in the city for no comprehensible reason, according to the witnesses I interviewed. ${ }^{20}$ As has been mentioned, no preparations had been made to receive the new arrivals, the local authorities did not know the Koreans' professions until the trains arrived and hence there were no plans to give Koreans jobs similar to those they previously exercised. ${ }^{21}$ Having being left in the city, the Koreans expected they would be given jobs as factory or clerical workers but instead many of them went for months without work, until they obtained authorization to move to the kolkhozy of their fellow Koreans. 
A Korean political elite cooperated with the official bodies responsible for settling the Koreans in the region. The Koreans had long experience of being a minority and were accustomed to being represented by an intermediary elite in dealings with government. This is the way it had been in the Far East at the time of their migration to the tsarist empire and the system was then reconstituted, although in different forms, in the Soviet state where it was the Communist Party that acted as an intermediary. No one had been exempt from the deportation from Korea-neither members of the party and of the Komsomol, nor the local intelligentsia (teachers, agronomists, doctors, etc.). ${ }^{22}$ It is likely that these were the people in the deported Korean community to whom the Soviet authorities turned, at least initially. The Koreans, let us recall, had never been accused of being traitors; they were deported only because it was believed they might commit treason. Consequently, their leaders were not denounced and repressed and they cooperated with deportation. When the Koreans arrived in Central Asia, they therefore already had a mediatory elite that had acquired a command of Russian and knew how to negotiate with the Soviets. There was little need for them to acquire a similar level of competence in Uzbek and Tajik.

The Koreans' assimilation in the Russian-speaking group in Samarkand thus began with their arrival in the city and was subsequently strengthened thanks to Soviet educational policies. At first the Soviet authorities had envisaged schools in which Koreans would have been taught in the mother tongue but the plan was abandoned for lack of funding and in 1938 the Korean pupils were already studying in the Soviet Union's most strategic language, while Tajiks and Uzbeks were for the most part being educated in their mother tongues. The Korean's success in Samarkand, and throughout Uzbekistan, was based on their ability to engage in dialogue directly with the Russian authorities.

The war offered Koreans new opportunities to improve their position. When the Russians and the local population of Samarkand were called up, new spaces opened up for these immigrants who were able to move in a Russian-speaking milieu. Koreans were not drafted and became a substitute workforce in the city, while in the country they grew rice and other foodstuffs that became absolute necessities in wartime.

\section{A Population that Changed}

Before investigating the fate of the Koreans in Samarkand and its region, we need to consider their presence in Uzbekistan, as documented by post-war censuses.

The censuses indicate constant growth in the number of people who identified themselves as Korean (see Table 1). Kazakhstan was the place to which the largest number of deportees were sent, but some of the Koreans moved away. A significant number moved from Kazakhstan to Uzbekistan in the 1950s. ${ }^{23}$ In 1989 Uzbekistan had the largest Korean community living in the USSR (see Table 2). There were also 
TABLE 1 Koreans in Uzbekistan, 1959-1989a

\begin{tabular}{lrrrr}
\hline & 1959 & 1970 & 1979 & 1989 \\
\hline Uzbekistan & & & & \\
Total & 138,451 & 147,563 & 163,062 & 183,140 \\
Cities & - & 85,417 & 117,327 & 146,077 \\
$\quad$ Country & - & 62,121 & 45,735 & 37,063 \\
Oblast of Samarkand & & 7,551 & 8,531 & 8,120 \\
$\quad$ Total & 6,491 & - & 7,700 & 7,556 \\
Cities & - & - & 831 & 564 \\
Country & - & & & \\
\hline
\end{tabular}

a'Itogi vsesoyuznoj perepisi naseleniya 1989 goda, vol. 1, 118-30; vol. Natsional'nyj sostav naseleniya, 51-68, 149-63; and Itogi vsesoyuznoj perepisi naseleniya 1970 goda, 202-10.

TABLE 2 Koreans in the USSR, 1989

\begin{tabular}{lc}
\hline Country & Number of Koreans \\
\hline Uzbekistan & 183,140 \\
Russia & 107,051 \\
Kazakhstan & 103,315 \\
Kyrgyzstan & 18,355 \\
Tajikistan & 13,431 \\
Other republics & 42,000 \\
Total & 438,650
\end{tabular}

a Itogi vsesoyuznoj perepisi naseleniya 1989 goda. Vol. IX, Natsional'nyj sostav naseleniya, $61-62,270-316,339-55$.

significant population shifts within Uzbekistan, from the countryside to cities. The growth of the Korean population in Tashkent was constant and led to nearly onequarter of the Koreans in the Uzbek Republic being resident in the capital city. This move to cities did not involve only the capital: in 1989, 80\% of Koreans lived in cities, and in the Samarkand oblast the percentage was even higher-93\% (see Table 1). In this oblast, two-thirds of the Koreans lived in the city of Samarkand. ${ }^{24}$

The data highlight a radical change in the Koreans' way of life: they went from a situation in which they established separate farming communities and were officially identified as spetspereselentsy to one in which they had the same rights as all other citizens and lived mainly in cities. The move to the city is an indication of greater integration in local society, and we will now examine this process. In order to do this, I wish to focus on the experience of a family, the family of Viktor Tsoj. ${ }^{25}$ I will use the history of this family as an exemplar and as the basis of my narrative. Along 
with interviews with members of other families this biographical material will help us grasp the complexity of the ups and downs in the lives of the Koreans in Samarkand from the end of the war to the present.

\section{Roads to Social Integration: Viktor Tsoj's Family and the First Steps Taken as Farmers}

Let us start with the family tree (see Figure 1).

Viktor Tsoj's family is small, similar in size to Russian families more than to Uzbek or Tajik ones. The given names of the family members are Russian, as nearly always happened among Koreans who were deported. The first step towards the Russian world was taken at birth, with the acquisition of a Russian name (pronouncing Korean names would have been difficult for both Russians and Uzbeks). The grandfather in this family, Ma In Doc, experienced deportation as an adult, and was therefore the only one who did not take a Russian name, within the family he represented the link with origins.

Viktor's parents, Boris Tsoj and Nadezhda Alekseevna Magaj arrived in the Tashkent oblast in 1938, deported there together with their parents; he was 11 and she was 3. Their families knew each other and were brought closer together by their common lot. Upon arrival, they were sent to live in huts on an Uzbek kolkhoz where they were given work. The mother tongue of the members of the two families was Korean. They knew hardly any Russian and had never heard Uzbek being spoken before arriving on the kolkhoz. They subsequently learned the language and became accustomed to the Uzbeks' way of life.

In the 1950s, most of the Korean families who lived on kolkhozy could speak Uzbek, while those who lived in cities were less likely to know it. Viktor's family continued to speak Korean at home and, like many of his peers, he grew up knowing his family's original language. As time passed, however, the situation changed and they also began to speak Russian among themselves. In other families with many children,

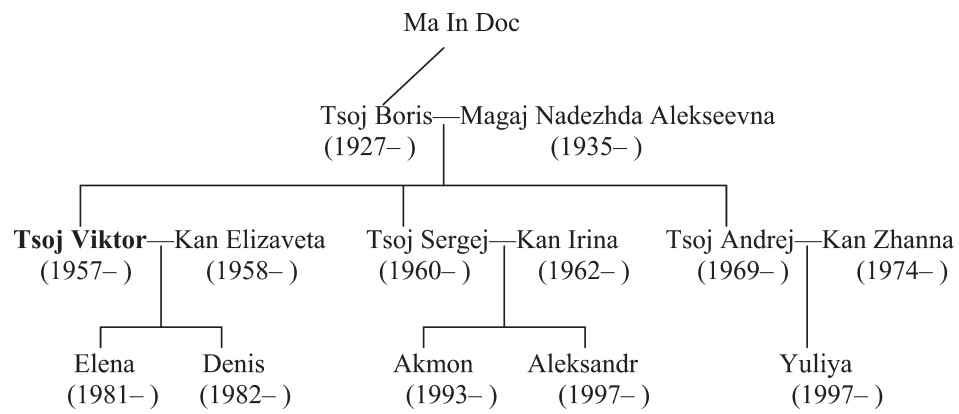

FIGURE 1 The Tsoj family tree. 
those who were born during the war and immediately afterwards learned Korean, while their younger siblings were mother-tongue speakers of Russian. ${ }^{26}$ Later, Korean would be forgotten.

In the post-war years, Boris and Nadezhda Alekseevna worked on several different kolkhozy in the Tashkent oblast. In 1956 they moved to a small village in the Samarkand oblast. Over the years, many of their relatives also moved there. Studying Viktor's family allows us to discover the ways in which the Koreans' kolkhozy differed from the Uzbeks'. From the Koreans' point of view, the kolkhoz owned the land and the work brigades the farmers were organized in, were groups of kin who worked the land rented from the kolkhoz. The kolkhoz furnished land, seeds and equipment and in exchange the Korean farmers had to give the state a certain quantity of rice. If production exceeded the amount agreed on, the farmers could sell the excess and keep the proceeds for themselves. Unlike the Uzbeks, who grew cotton and whose entire crop was bought by the state, part of the rice and vegetables the Koreans grew could be sold on the market and this allowed them to earn a profit. It was in their interest to produce as much as possible and therefore everyone worked: men, women and children. On their kolkhozy, there was no pay based on the trudoden, the number of days worked, as there was on Uzbek kolkhozy. ${ }^{27}$ On the collective farms, the Koreans were highly entrepreneurial and their entrepreneurship was based on family ties. Koreans, interviewees often told me, love work and devote themselves to producing and selling, and their attitude was different from that of the Uzbek farmers. Their system for organizing work was not strictly legal and therefore is not described in official documents. It probably began in the post-war years, but it was in the 1960s that it became widespread. It remained in force until the collapse of the Soviet Union. Although not officially recognized by the authorities, it was tolerated in practice. The way land was leased on the kolkhozy suggests two interesting analogies: it recalls the system that existed in the Far East, when landless Korean immigrants with few rights rented fields from Russian colonists and Cossacks; in addition, it is a forerunner of the system that became widespread among the Uzbek farmers with the reform of the kolkhozy that followed the collapse of the USSR.

Let us return to Viktor's family. The father, Boris, who was unschooled but intelligent and honest, in time became the bookkeeper on his kolkhoz, in charge of paying workers their salaries. He then became the head of one of the farm's 10 work brigades. His collective grew rice; his brigade had 15 members and the land they were given to work was divided into 15 parts. The plot allotted to each was cultivated by the entire family, including children and the elderly. In practice they exploited for themselves a plot of land which legally belonged to the kolkhoz, but in fact was a family holding. Their main crop was rice and they had to give the kolkhoz part of the harvest. By working hard, they always managed to exceed production quotas and could keep what they were not obliged to hand over to the state and sell it on their own. Boris and Nadezhda Alekseevna lived in a house near 
the kolkhoz's administrative office and part of the work Boris did was in the office, while the rest was in fields about 10 kilometers away. The family was well-off.

Their relative prosperity was common among Korean kolkhozniks. Their business acumen made them relatively rich and many were able to buy a house in the city for their family. This trend towards moving to the city was already strong in the 1950s and led to an important change in the entire Korean community's status in Uzbekistan society. It is therefore useful to investigate the reasons for this choice. For sure, there were jobs in the city. In the post-war years, in fact, the factories set up by the Russians were expanding, but many of the workers evacuated to Uzbekistan chose to return to their native cities. Thus a new workforce-both workers and technical personnel-was being sought. In Samarkand the demand was met largely by Crimean Tatars, another group of deportees. ${ }^{28}$ In the years immediately after the war, however, Koreans were scarcely attracted by the opportunity to be factory workers, and only later would they apply for jobs as technicians and specialists. As it was therefore not the factory that drew Koreans to the cities en masse, and in the city there were no other job opportunities, the explanation for the move needs to be sought in what was happening in the country.

With the end of the war, Uzbeks who had fought in the Soviet army returned to the country areas in their native republic. They were numerous and their return made the labor of the Koreans on Uzbek kolkhozy superfluous. In time, the activities of even the Korean kolkhozy were called into question. A witness related that in the late 1950s he and his family moved to a small city near Samarkand because the Korean kolkhoz they had been working on was closed. He affirmed that the majority of Korean farmers met the same fate. ${ }^{29}$ The land of the Korean kolkhozy was once again controlled by Uzbeks. This probably occurred as the result of pressure from Uzbeks, who wanted more land, and was made possible by the agrarian reform which Khrushchev wanted imposed throughout the USSR, the objective of which was to create large collective farms by bringing together smaller ones. The land of the small Korean kolkhozy in the Samarkand oblast therefore had to become part of the Uzbek kolkhozy near them.

In terms of farm management, the reform had a certain logic. It was found, in fact, that cultivating rice is useful for eliminating excessive salinity so that fields could easily be converted to growing sorghum, and a few years afterwards to cotton. The process is believed to be an excellent way to obtain fields for cultivating cotton. ${ }^{30}$ In this way, land belonging to Uzbek farmers that previously had not been seen as suitable for farming was transformed through the work of the Koreans and could be used for growing cotton under the plan decreed by the Soviet authorities and implanted by the Uzbeks.

One witness thought that the Korean kolkhozy were closed because they were too rich. In any case, the unification process had two negative outcomes for the Koreans. The first was that their incomes went down; the second that management of the collective farms was taken from them and handed over to Uzbeks. There was a 
clear connection between the two, as one witness pointed out: the Uzbeks put in charge were not people who cared about production; their only interest was to get their hands on rich farmland and divide it up among their families. It was these changes that impoverished the Koreans and forced them to leave for the city. ${ }^{31}$ As had happened in the earliest period of settlement in Uzbekistan, the Koreans' separation from Uzbek peasants and their move to the city was also a positive step that gave them upward social mobility and a way into the Russian world.

The new opportunities open to them in cities did not involve a complete break with village life. Not all the Korean kolkhozy closed, and many of the Koreans who moved to the city maintained their ties with the country. They were aware that the roots of their well-being were in the country, and it was from there that the resources enabling them to construct new lives in the city would come. Exploiting their links with their former kolkhozy, the new city dwellers went to the country and worked on the land for part of the year; during the remainder of the year they worked or studied in the city, where they hoped to build a future. This new relationship with the land rendered more explicit the special nature of Korean agriculture, which lay in its being based on renting fields. Starting in the 1950s there was a change in the relationship between Koreans and Uzbek farmers: the former worked the land they rented independently and intensively, while the latter earned an income for the work they did. It was a system that guaranteed the Koreans good profits because they were able to use intensive methods to grow rice and vegetables, and their families in the city took charge of selling the produce at street markets or shipping it to Russia. Salaries in the city were low, but trading in foodstuffs grown on the kolkhozy allowed families to earn a good living. ${ }^{32}$

Viktor Tsoj, born in 1957, recalls that in the late 1960s his family was living quite well and in their house they had everything they needed. His parents took summer vacations, did not have financial difficulties, and even bought a Moskvich car. His relatives also had comfortable houses. His father, Boris, had become a party member, held a position of responsibility and was respected by the management of the kolkhoz, the people on the kolkhoz, and neighbors. He would do this work until he retired. Another witness comes from a family which he described as poor. In the 1960s, his father, who was a farmer and would be one for his entire life, managed to buy a house in Samarkand in the quarter called Shanghaj. The house was small and crowded: 13 people-adults and children-lived in two rooms. Later the family bought a car. In the meantime, all the children had attended Russian schools. The family's income varied from year to year because it depended on the contract the father was able to stipulate with the kolkhoz and the quantity of rice and onions he was able to grow and sell. ${ }^{33}$

Starting in the 1950s, farming methods, including those of the Koreans, began to be modernized. New machinery and tractor stations (MTSs) were set up and dealt with requests from the kolkhozy. Based on the requests it received, the MTS drew up a plan for using its farm machinery and this was then approved by the party. In this 
way, the party, working through the local MTS, made decisions which deeply affected the farmers' lives. Modernization of production was indissolubly linked to the Russian world: the party was directed from Moscow; tractors, harvesters and other farm machinery arrived directly from Russian factories and factories evacuated to Uzbekistan during the war. Russian specialists arrived with the factories and were flanked by Russian-speaking technicians, many of them members of deported minorities (mainly Germans and Crimean Tatars) chosen by the party.

It was in this way that people who spoke Russian arrived on the kolkhoz where Viktor's parents worked. The first director of the MTS serving their kolkhoz was a German. There were also many Russians working in the MTS, doing a range of jobs, from engineers to workers. Every kolkhoz needed what were called "mechanizers," as it had to organize courses to train people to use the new farm equipment. The Koreans had their farm brigades and received the training and the equipment they needed from the MTS. Teaching was in Russian. The modernization of production methods brought with it upward social mobility-mobility towards the Russian world. Koreans who worked on kolkhozy realized how important it was for them to learn Russian. In the post-war years, the first classes with teaching in Russian were formed in the schools of the Uzbek kishlaks, and kolkhoz directors began sending their children to them. The trend then became widespread and schools were opened where all teaching was in Russian. Korean children born in Uzbekistan from peasant parents attended Russian classes starting in the 1940s: they picked up Uzbek in the streets but their parents made sure they learned Russian to ensure future success. Near Samarkand, in Juma, on the all-Korean Karl Marx Kolkhoz, a Russian-speaking school was opened and the person chosen to be its first principal was a Korean.

\section{In the City: The Process of Assimilation}

Viktor spoke Korean at home as a child. He had Uzbek neighbors and spoke Uzbek with his friends. The Korean, Uzbek and Russian children in his nursery school spoke a mixed language with one another. Viktor understood Russian by the time he started school. He attended the Russian school whose principal was Korean. Only Russian was spoken there. By the time he finished school, Viktor thought in Russian, and the rest of his education was in Russian. He went to a Russian institute, then studied at the Faculty of Russian Philology at the University of Samarkand. His case is not anomalous. All Korean children of his generation studied in Russian and, even more than Viktor, tended to forget Korean.

At the age of 23, Viktor married Elizaveta, a year younger than him. She had a secondary-school education and could speak Korean and Russian but not Uzbek. When she finished school, Elizaveta had found a job at Liftostrojetel'nyj zavod (an elevator factory), one of the largest plants evacuated to Samarkand during the war, and had 
worked there for five years. Viktor and Elizaveta's move to the city is an indication of upward social mobility: from the separateness of the Korean village to the city, with its opportunities for self-improvement represented by Russian culture and factory jobs. In this respect as well, their lives are similar to those of many of their co-nationals.

Under Brezhnev, when "mature socialism" came into vogue, the Koreans were seen as educated and did intellectual jobs. They were doctors, teachers, people of culture. Many of them held political office or had positions of responsibility. In the 1980s some of the most important factories in Samarkand had Koreans as directors: Liftostrojetel'nyj zavod (where Elizaveta worked), Khopkomash, Kinap, a refrigerator factory, the vinzavod (wine-bottling plant), and the Khimstorj organization. Koreans also headed construction companies, hospitals and schools. ${ }^{34}$

A further example of social success was provided by another of our witnesses, Petr Li. Born during the war, son of a Korean woman deported to Uzbekistan and a Russian soldier, he attended Russian schools and obtained a diploma as a technician. He did his military service, enrolled in the party and became a manager at Kinap. ${ }^{35}$

Viktor Tsoj explained that in the 1980s the Koreans were one of the most prosperous groups in the city and enjoyed the well-deserved respect of the local population. Their process of social improvement had begun with the income earned on the kolkhozy, invested so that they could move to the city and send their children to Russian schools. The higher social status they achieved in the city had its downside, however, as it tended to lead to the loss of Korean culture and in the long run to the disappearance of the Koreans as a community. In the 1970s the regime in fact extolled and encouraged the overcoming of national cultures and the emergence of Soviet citizens who shared a common language and culture. In reality, the propaganda envisaged a future that never materialized. Assimilation with Russian culture and social improvement through the Soviet state's institutions did not bring about the disappearance of the Korean community. One indication is the extremely low percentage of mixed marriages.

One witness said that endogamy was strictly observed by the first generations after deportation, while among the younger generations, albeit infrequently, there were mixed marriages. ${ }^{36}$ Another witness confirmed that these marriages were rare until the early 1980s, while the number increased in the last years of Soviet rule and immediately afterwards. ${ }^{37} \mathrm{~A}$ third witness asserted that in recent years the tendency had reversed and that the percentage of mixed-marriage families among Koreans in Samarkand was probably no higher than $1 \%$ in $2006 .{ }^{38}$ Although clearly we are dealing with estimates that reflect the direct experience of each witness, the USSR certainly did not lead to the disappearance of the Korean community. The trend towards assimilation was probably interrupted when, in the midst of the general post-Soviet crisis in Uzbekistan, national communities began to withdraw into themselves. Before examining this reversal of the previous trend, we still need to consider the Korean community in the last years of Soviet rule to understand how the younger generations are coming to grips with a post-Soviet future whose developments they cannot predict. 
Viktor pointed out the relevance of cultural differences between generations and argued that Korean society could be seen as being divided into four generations. The first of these is made up of people born in Korea before 1920, who moved to Russia to find work. People in the second generation, that of Viktor's parents, were born in Primorskij Kraj, while those of the third, like Viktor, were born in Uzbekistan. The fourth, youngest generation, is that of Viktor's children. The cultural distance between generations is largely due to the process of urbanization and therefore to changes in the work people do. Viktor estimates that these changes can be quantified as shown in Table 3.

In his reconstruction the move towards the Russian language is a further significant indicator of the difference between generations.

The first two generations fully observed Korean traditions; the third generation knew the most important traditions and festive days and observed them but saw Uzbekistan as their homeland and, in addition to Korean, spoke Uzbek and Russian; the fourth generation had hardly any knowledge of the Korean language and traditions and had Russian as their mother tongue. The gap is really between the first two generations and those born in Uzbekistan. It is the children of the deportees who were most affected by integration in an urban society that was pluri-national and Russian speaking.

We find these transformation reflected in Viktor's family. We already know about Viktor and Elizaveta's lives. We will now turn attention to his siblings and their spouses. Viktor's brother, Sergej, born in 1960, attended Tashkent's secondary school for the arts and now works as a graphic designer in Fergana. He knows Russian and Uzbek and understands, but does not speak, Korean. Irina, his wife, attended a technical school, then worked as a bookkeeper for several different firms. She too knows Russian and Uzbek and understands Korean but does not speak it. Viktor's other brother, Andrej, graduated from the University of Samarkand, where he studied Russian philology. He then worked as a Russian teacher in a Russian school. He knows Uzbek and understands but does not speak Korean. Zhanna, his wife, also studied Russian philology at university. She understands Uzbek and Korean but does not speak these languages.

Viktor and his brothers followed paths which in some ways are typical of their generation. Let us now consider their children. Elena, Viktor and Elizaveta's daughter,

TABLE 3 Koreans working in agriculture ${ }^{\mathrm{a}}$

\begin{tabular}{lcccc}
\hline & $\begin{array}{c}\text { First generation } \\
\text { (born before } \\
\text { 1920) }(\%)\end{array}$ & $\begin{array}{c}\text { Second generation } \\
\text { (born 1920- } \\
\text { 1950) }(\%)\end{array}$ & $\begin{array}{c}\text { Third generation } \\
\text { (born 1950- } \\
1980)(\%)\end{array}$ & $\begin{array}{c}\text { Fourth generation } \\
\text { (born after 1980) } \\
(\%)\end{array}$ \\
\hline Farmers $(\%)$ & 98.5 & 90 & 40 & 2 \\
\hline
\end{tabular}

${ }^{\text {a }}$ This table and Table 4 show estimates made by Viktor. See also Kim, Korejtsy Respubliki Uzbekistan (istoriya i sovremennost'), 12. 
TABLE 4 Knowledge of Korean

\begin{tabular}{lccc}
\hline Generation & Excellent (\%) & Elementary $(\%)$ & None (\%) \\
\hline First & 100 & - & - \\
Second & 85 & 13 & 2 \\
Third & 30 & 30 & 40 \\
Fourth & - & 20 & 80 \\
\hline
\end{tabular}

knows Russian and English. Their son, Denis, knows Russian and Uzbek. Both of them understand Korean because when they were small they lived with their grandparents, but no longer use it and know nothing about Korean traditions. Viktor's brothers' children instead know only Russian.

Receiving all instruction in Russian for over half a century and living in an increasingly urban environment dominated by Russian culture transformed what was once a community of deported farm workers. The Koreans' level of schooling contrasts sharply with that of the Uzbeks': more than $75 \%$ of young Uzbeks attend schools where teaching is in Uzbek; they know Russian but their education has not been in Russian. ${ }^{39}$ The difference in schooling compared to the local population contributed significantly to the Koreans' upward social mobility.

In a letter to the Politburo written in 1988, five elderly Koreans in the Tashkent region asked to be told whether the decree which condemned them to deportation had ever been revoked. If it had, they wanted to know the reasons why this information had never been made public. They then asked for equal rights and explained that Koreans had become integrated in Russian society to such an extent that Korean children spoke to each other, their parents and old people only in Russian. ${ }^{40}$ If we consider the work they do and the language they speak, as a Korean historian wrote, "They are no longer Koreans, although they have not completely become Russians." 41

\section{After the Collapse of the USSR: Those Who Have Remained and Those Who Have Left}

When the Soviet regime fell and the country became independent, life in Uzbekistan changed radically. The new government adopted nationalistic rhetoric and set itself the task of championing affirmative action for Uzbeks. They were to be the masters of the new nation. The situation was no different from that in many other republics and here, as elsewhere, the distance between the nationality titular of the republic and the other nationalities grew considerably. Russians, the deported minorities, and even members of autochthonous minorities, found themselves in a new position and 
with severely reduced opportunities. There was no violence, but discrimination in favor of Uzbeks crept in, forcing others to leave their jobs and houses, and finally the republic. If prior to the collapse of the regime the administrators had used the attribution of each person to a national group to bureaucratically construct social integration, afterwards the same distinctions were used to create a new disparity in rights. The situation was further exacerbated by the economic crisis that made minorities particularly vulnerable.

This new precarious situation was forcing the Koreans to make entirely new kinds of choices. It was no longer possible to pursue the old strategies and forge their future on the basis of their experience of Soviet life, nor could they be certain of what their rights were. We will trace the broad outlines of these new directions, examining how individual choices contributed to shape new collective behavior.

The turning point in their lives was when it was decided that the language used in the workplace would henceforth be Uzbek instead of Russian. The decree which established this was issued in 1994 and it was then that Russians and other Russianspeaking people understood that the space open to them was shrinking and that their prospects were becoming less hopeful. Many of the Koreans who lost their jobs attempted to open a small private "biznes." 42

Viktor and Elizaveta lived in a quarter of the city that for a time underwent rapid growth. The quarter, called Sattepo, came into being in the early 1970s and developed rapidly in the 1980s with the construction of large tower blocks of mini-apartments. Most of the housing was built by the city's factories for their workers and the inhabitants were prevalently Russians and other Europeans. Viktor and Elizaveta's apartment was in one of the oldest buildings and their fate seems to have followed that of the quarter: relative prosperity in the 1980s followed by economic crisis, which led to many of their neighbors losing jobs.

Viktor, who worked at the university, was forced to resign because his faculty, Slavic Philology, lacked funds and its student enrolment was decreasing year by year. He began to do several jobs at the same time, organizing extracurricular activities in a middle school, offering a few hours of teaching per week in another school, engaging in commercial activities and small business dealings. Elizaveta worked in a factory until the end of the 1990s. Then she stopped working regularly because the factory reduced production and seldom paid the workforce, reaching the point when it did not pay most of them for two full years. In 2004 Elizaveta was obliged to formally resign.

Factories were closing. Non-Uzbeks were being pushed out of the civil service. The Koreans compensated for the loss of jobs in these sectors by shifting their entrepreneurship towards the private sector. They tended to become what in Russian are called "biznesmen." Initially business seemed to be booming and hopes were high.

For a while many Koreans held down more than one job so their total income would be enough to live on. They left to work abroad for relatively brief periods, from a few 
months to two to three years, to earn money to invest in private economic activities when they returned to Uzbekistan. In the late 1990s, Viktor went first to Russia, then to Korea. These were the destinations most often chosen during the large-scale temporary emigration from Uzbekistan that occurred at the time. When he returned from Korea, Viktor started a small artisan firm in Samarkand and the company did well for two years. Then his success created envy and attracted the interest of people who had the power to persuade Viktor to back out.

For the temporary emigrants, problems began when they returned. The deteriorating economic situation, the growing restrictions on commerce and the authorities' continual prevarications caused the failure of many of the Koreans' attempts at entrepreneurship. What were left were a few activities which can now be considered typically Korean: selling salads at the bazaar, wholesaling onions and exporting them to city markets in Russia. Growing rice, once their principal occupation, is now undertaken principally by Uzbeks.

The government is increasingly becoming dominated by Uzbeks, and for nonUzbeks, not only the Koreans, there is less and less space, even in the private sector (which in reality continued to depend heavily on the state). We are witnessing the same process in Kazakhstan: Kazakhstanization is causing the expulsion, among others, of large numbers of Koreans from the ranks of the civil service. ${ }^{43}$ In Kazakhstan, which is a far more open country than Uzbekistan, commerce and the private sector are, however, expanding, offering an alternative to working for the state.

The Koreans in Uzbekistan were therefore forced to see emigration in a different light: no longer as a temporary situation that allowed them to earn money to invest in Uzbekistan, but as a definitive choice, and in the mid-1990s they began to emigrate. Their departure from the city had high visibility in that the quarter the majority of the Koreans lived in, known as Shanghaj, emptied. Shanghaj (whose name derived from the conviction that everyone who has Oriental features is Chinese or, as one of my witnesses maintained, one that suggests a chaotic quarter, like a Chinese city?) was quite a particular mahalla, made up of small private dwellings, constructed following the whims of each family, without benefit of city planning. It had a reputation as being a district that was rarely subject to police control, where criminality was rife. It is true that Koreans gamble and it is said that large sums of money circulated in the quarter. In reality, it was a neighborhood with a mixed population. In addition to Koreans, there were Crimean Tatars, a few Armenians, and Meshket Turks. Russian was spoken in the streets. Now, after emigration, one encounters few Koreans and the Crimean Tatars have disappeared. Some of the houses where Koreans lived still belong to them, even though their inhabitants, or many of them, have left. Many of the houses were bought by Uzbeks, who came to live in Samarkand from kishlaks near the city. In fact the language one now hears spoken in the streets of the mahalla is Uzbek.

It is difficult to estimate how many of Shanghaj's Korean residents have left. According to Liron Magaj, one-third of the families of Shanghaj have emigrated in 
their entirety and the remaining ones have half of their members living abroad. This means that over half of the district's Korean inhabitants no longer live there. According to another Korean, the minister of a Presbyterian church in another quarter, formerly half of Shanghaj's residents were Korean, while in 2006 less than 10\% were. These are subjective estimates, which, however, leave no doubt as to the scale of Korean emigration. ${ }^{44}$

It is children and the elderly who have stayed in Samarkand-grandparents, their grandchildren and great-grandchildren - while people of working age have emigrated and are trying to earn enough to make the rest of their family join them. Yet not everyone wants to leave. This is true, for example, of Antonina Han. ${ }^{45}$ She is still working as assistant director of a library but no longer hopes to become director and will retire soon. She divorced her Korean husband many years ago and their son is now an adult. She lives alone but has become the "second wife" of a Tatar. They see each other regularly and drink heavily. When I interviewed her, her son was going to leave for Moscow with his wife and son in a few months. Antonina had no other relatives left in Samarkand. The only thing she could do would be to go to Moscow and sell Korean food at the bazaar, but she did not want to work there. She stayed for lack of alternatives, yet she said it was no longer possible to live in Samarkand.

\section{Remaking the Korean Community}

The marginal position in which the Koreans have now been placed and their shared experience is creating a closeness that seems to presage the re-emergence of a close-knit Korean community. In order to cope with insecurity and devise new strategies, many tend to re-evaluate their family ties and group origins. Those who intend to remain in Samarkand will turn to them in order to find work, while those who want to leave will use these connections to enable them to go elsewhere.

The activism with which people are reconstructing their lives, as has been seen, to some extent derives from collective hopes based on a sense of shared nationality. The distant interlocutor is Korea, which contributes to these sentiments by investing in Uzbekistan and creating a situation in which, in the language of diplomatic relations, references to the Koreans of Uzbekistan and interest in their fate are recurrent themes (as will be seen below, this does not mean that Korea intends to open its doors to them).

Activities and rituals whose objective is to promote a sense of belonging to a community are developing through initiative both from outside (Korea) and inside (Uzbekistan's Koreans). A prime aspect of this new identity construction is religion, but not a return to the religion of the distant past. Their ancestors' Buddhism was forgotten with the passing of generations and today a large majority of Soviet Koreans are non-believers. Decades of Soviet repression of religion and traditions and the processes of assimilation and Russification that the Koreans went through created 
such a break that it would be difficult for them to return to their traditional religion. The one that now unites the Korean community is Presbyterianism, which with support from the United Church of South Korea (Obedinënnaya Tsekov Yuzhnoj Korei), came to Uzbekistan. This religion, hitherto unknown to Koreans in Central Asia, was spread by missionaries from South Korea and the US who began to appear in the mid-1990s. They brought funding with them and built churches in all the cities in the republic. Five Protestant churches were built in Samarkand and a large part of the Korean community attends a religious service at least once a week. Some of the ministers are citizens of South Korea, while others are Uzbekistani Koreans who trained in Korea, where young Korean candidates for the ministry are sent to work as clergymen for short periods of time. In Samarkand's Korean churches, the sermons are normally preached in Russian, but once a week are in Korean. The churches organize free courses on Korean language and computer skills, as well as other cultural activities.

One of Samarkand's Presbyterian churches was built in the mahalla Shanghaj in the early 1990s. It is an enormous building with a hall for services and sermons, a smaller prayer room, a nursery school, a language laboratory, choir practice and music rooms, and an apartment for the minister and his family. The church rapidly became an important meeting place for district residents. Today, however, it is closed. On Sundays the faithful among Shanghaj's shrinking Korean community are taken by bus to the church in Super, on the city's outskirts, an area that was once a working-class neighborhood. Just over 100 people participate in the Sunday service. A similar crowd attend the church in the Mikrorajon district. Their numbers are dwindling as Koreans continue to emigrate. The sermons I heard in these churches point to a simple religious faith which calls for brotherhood and distinguishes clearly between good and evil. The minister explained this simplicity to me through a comparison with other religions: in mosques, he said, the mullahs pray in Arabic and the faithful do not understand his words; in Orthodox churches, the priests wear strange ceremonial trappings and the rituals are complicated; in Presbyterian churches, the ministers are dressed like the congregation and speak a language everyone understands. It was this, in his view, that accounted for the rapid spread of this religion. ${ }^{46}$

While telling me about his life, Sasha Pak, one of the Presbyterian ministers I met, described a significant pattern of development. Under the Soviets he was a science teacher, atheist and party member. He first read religious texts in the early 1990s and five years later was invited to Korea to study for the ministry. When he returned he attended a seminary in Samarkand (the seminary has since moved to Tashkent), but he confided in me that at the time he still did not fully believe in religion. Then, he told me, God won. His story, in synthesis, describes the labor pains of going from one certitude to another. It is one of the paths open to people who until 1991 thought of their future in one way and then brusquely had to adapt to the idea that what awaited them was a very different world from the one they had expected.

Cultural clubs are another means of constructing collective identity. The one in Samarkand opened in the mid-1990s and has organized celebrations for the 
community's anniversaries, as well as courses and other cultural activities. In the years since then, cultural circles have been established in all cities with Korean communities. There are different approaches concerning, in particular, relations with South Korea: some centers simply organize cultural activities for the Koreans in Uzbekistan, while others favor contacts with the "re-found" motherland. ${ }^{47}$

\section{The Fate of Those Who Emigrate}

Koreans who emigrate from Uzbekistan follow the opposite route from that taken before the war: many have gone to Kazakhstan, many to Russia, and some to the Far East. This is not in contradiction with the feeling of belonging, which has been discussed above. The Koreans' family networks have in fact become stronger because people are reactivating contacts with distant relatives, while the new migratory wave provides opportunities in new territories. In this way, the new migrants also rediscover the idea that a community exists and represents an indispensable resource for each of its members.

When I interviewed Viktor Tsoj in Samarkand in 2005 he estimated that out of 100 Koreans in Samarkand, 70 of them were emigrants-30 temporarily and 40 definitively. These figures are roughly the same as those given by other interviewees in the Shanghaj mahalla. Of the 70 emigrants, about 50 have gone to Russia, 10 to Kazakhstan and 10 to other countries. By following the story of Viktor and his family we can explore the fate of these emigrants who will not return.

Viktor has relatives in Tashkent, Kazakhstan, Moscow and the Far East. After exploring the various possibilities for emigration, he decided to leave, remaining, however, in Central Asia. He and his wife went to Bishkek in Kyrgyzstan, where a brother of his wife and other relatives were already living. Viktor's first move had been to Moscow. He and a friend bought machinery and opened a small furniture factory, but in Moscow, as had already happened in Samarkand, he was not allowed to enter the market. He closed the company, sold the machinery, and used the money he recovered to start up a new business in Bishkek. Viktor knew many people in the city, where he had studied as a young man. There were no problems with language in that everyone there speaks Russian.

His son, who lived in the Sattepo district, was a teacher with a very low salary. He moved to Almaty in Kazakhstan to work with an uncle in business there. Viktor's daughter now lives in Kazakhstan, too, but with relatives in another city. Viktor, Elizaveta and their children are the last in their families to have left Samarkand. One of Viktor's brothers moved to Russia in the mid-1990s; five years later the other brother, together with his elderly parents, also moved there. One of the brothers works in commerce and now lives in Primorskij Kraj in the Far East. Viktor saw him in Tashkent in 2005 at the anniversary of the death (paminki) of a close relative. Among the Koreans it is customary to reunite the entire family on the first three anniversaries of the death 
of a family member. The third anniversary is the most important because if relatives live far away, they may not see each other again. In fact Viktor thinks he will not have another opportunity to see his brother, who, after the paminki, returned to the Far East. Seventeen other family members have emigrated, some to Russia, others to Kyrgyzstan or Korea.

The majority of the Korean emigrants from Samarkand went to Russia. Today, they have networks - most of them based on family ties - that extend from the regions bordering on Central Asia to Moscow and Siberia. Some Koreans have even moved to the Far East, and about 10,000 of them, from different parts of Russia and Central Asia, have settled in Primorskij Kraj. ${ }^{48}$ In their newly established contacts with the Orient, we witness the role of a particular part of the Korean diaspora, people who during the Second World War settled in the southern part of the island of Sakhalin and at the end of the war, when the USSR took over, became Soviet citizens. There was emigration of Koreans from Sakhalin to western Russia and Central Asia, but many remained on the island. In the same years there was also movement in the opposite direction: Korean party activists were sent to Sakhalin to construct the Soviet regime and act as intermediaries with local people who did not speak Russian. After the collapse of the USSR, Koreans on Sakhalin found they could play a vital role in commerce between Russia and South Korea. Their knowledge of Russian and a variant of Korean very similar to the language spoken in Seoul allowed them to act as intermediaries. ${ }^{49}$

For the majority of Koreans, however, it has not been easy to establish a relationship of this sort. They do not know the language and have a culture that is far removed from Korea's. They lack the money and contacts to be able to work in international commerce. ${ }^{50}$ For very few of Uzbekistan's Koreans is Korea-their mythic place of origin and a land of prosperity for those able to reach it - a country with which they have any real ties.

\section{Conclusion}

When the Koreans arrived in the Samarkand region as a deported minority, they created national enclaves on kolkhozy and in a few scattered settlements in cities. Working in the country and growing rice were the first steps in a process that would bring them to the city and allow them to hold positions of responsibility within the civil service system. As this was happening, the Koreans distanced themselves from their traditions and even lost the ability to speak their ancestral language, becoming to all intents and purposes Russian-speaking Soviet citizens. Their existence as a community did not, however, come to an end. It was perpetuated in three forms: family ties and preference for endogamy; the bureaucratic notation "Korean nationality" in their passports, which affected their lives, as the lives of all citizens of the USSR were similarly affected; and the physical features which made it possible for them to be identified as Koreans ... from Shanghaj. These are the aspects that constitute their 
legacy from the past and at the same time the possibility of recognizing themselves as part of a community in the future. If the Soviet system had not collapsed, the result of assimilation might have been that their sense of belonging to a distinct community would have disappeared, in time. Instead, the collapse of the USSR caused a reversal of this trend. It re-created the Koreans. They are Koreans of the younger generations who construct their social identity by linking memories of the past to new ties of citizens of a world that is no longer rigidly closed. The new Koreans are taking the entrepreneurial ability of their families out of the public sector and applying it in the private one. They move wherever they can, creating new relational networks and new types of work. They are reconstructing the myth of their origins whose ideal was Korea, and they are once again learning Korean, as it is now a useful language for them to know.

\section{NOTES}

*Translated from Italian by Susan Finnel.

1. My estimates are based on data in Gosudarstvennyj Arkhiv Samarkanskoj Oblasti (henceforth referred to as GASO) 913/1/113/307-308, 1073/1/10/18, 74/1/242/16-20.

2. Bugaj, L. Beriya-I. Stalinu, 23. An important study containing data and original documents is Bugaj, Korejtsy v Soyuze SSR-Rossii:XX-j vek.

3. Rakhmankulova, "Ob ispol'zovanii trudovogo potentsiala deportirovannykh narodov $\mathrm{v}$ Uzbekistane v kontse 1930-kh-1940-e gody," 153.

4. Polyan, Ne po svoej vole, 93.

5. Census figures for 1939: GASO 1515/1/3810/267.

6. Interview with Viktor Tsoj (see below). I have not used the real names of the people interviewed.

7. Decision of the Uzbekistan Sovnarkom, 4 January 1940: GASO 1073/1/4/21-22.

8. Kim, Korejtsy Respubliki Uzbekistan, 56-61.

9. Polyan, Ne po svoej vole, 91.

10. GASO $1073 / 1 / 4 / 31$.

11. This was stressed by Viktor Tsoj.

12. Kim, Istoriya immigratsii korejtsev, 198.

13. Resolution of the Ispolkom (executive committee) of the soviet of the Samarkand oblast, 13 February 1940: GASO 1073/1/1/11-14.

14. Ibid., $1073 / 1 / 51-52$ and $1073 / 1 / 3 / 29$.

15. Document dated 10 October 1940, in GASO 1073/1/4/12-14.

16. At the beginning of 1940, the Sovnarkom of the USSR and then the one in Tashkent passed a series of provisions to boost cotton cultivation as the principal agricultural product in Uzbekistan. GASO 1073/1/1/8-10.

17. Bezugol'nyj, Narody Kavkaza v Vooruzhennykh silakh SSSR v gody Velikoj Otechestvennoj vojny, 1941-1945 gg.

18. Kim, Korejtsy Respubliki Uzbekistan, 27-32.

19. Kim, Istoriya immigratsii korejtsev, 200-01.

20. Interview with Sasha Pak, pastor of the Protestant church in the Mikrorajon quarter of Samarkand, late September 2006.

21. Rakhmankulova, "Ob ispol'zovanii trudovogo potentsiala deportirovannykh narodov v Uzbekistane v kontse 1930-kh-1940-e gody," 153. 
22. A directive issued by the party krajkom on 25 September 1937 explicitly states that professionals were to be deported together with the rest of the population. The document is published in Pobol' and Polyan, Stalinskie deportatsii, 1928-1953, 90.

23. There were 77,000 in Uzbekistan in 1945 and 138,000 in 1959. It is likely that many of the moves were unauthorized and were recorded only in the 1959 census, i.e. when the Koreans officially had the right to move.

24. There were 4,836 people: Kim, Korejtsy Respubliki Uzbekistan, 174.

25. The person I will call Viktor Tsoj is of Korean nationality and his relatives, friends and colleagues are Koreans. He is my primary witness from his family. I met him several times in his home, in the street, and at the home of mutual friends in Samarkand during the first four months of 2005. I interviewed him in conversations which were unplanned and in which I did not pose questions, and I subsequently undertook more systematic interviews on specific questions. He also passed to me written notes and texts about his family. Viktor is a teacher, an educated person, and has a great capacity for observing people's lives and interpreting the ongoing social changes.

26. This is the case of the Liron Magaj's family, which I interviewed in their house in the Shanghaj quarter on 15 September 2006.

27. Kim, Korejtsy Respubliki Uzbekistan, 108, 136.

28. Rakhmankulova, "Ob ispol'zovanii trudovogo potentsiala deportirovannykh narodov $\mathrm{v}$ Uzbekistane v kontse 1930-kh-1940-e gody," 158.

29. Interview with Sasha Pak.

30. Dzharylgasinova, "Osnovnye tendentsii etnicheskikh protsessov u korejtsev Srednej Azii i Kazakhstana," 47.

31. Interview with Sasha Pak.

32. Interview with Andrej Kim, minister of the Protestant church in the Shanghaj quarter, conducted in the church on 21 September 2006.

33. Interview with Liron Magaj.

34. Interview with Viktor Tsoj.

35. Interview with Petr Li, conducted at his home in April 2005.

36. Ibid.

37. Interview with Andrej Kim.

38. Interview with Sasha Pak.

39. The most recent Soviet figures available indicate that in Samarkand, in 1986/1987, there were 30,761 Uzbek students in elementary and secondary school. Of these, 23,292 were in classes where teaching was in Uzbek. GASO 7/1/1066/115-116.

40. Kim, Tumangan, 125, 129.

41. Pak, Potomki strany belykh aistov, 11.

42. Interview with Andrej Kim.

43. Oka, "Korejtsy v sovremennom Kazakhstane," 197-99; Oh, "Diaspora Nationalism," $122-24$.

44. Interviews with Liron Magaj, Sasha Pak, and Andrej Kim.

45. Interviewed in her house in Samarkand, 21 and 25 March 2005.

46. I attended services in these churches, spoke with members of the congregation and interviewed ministers in September 2006.

47. Kim and Khan, "Aktual'nye problemy korejskoj diaspory v Tsentral'noj Azii," 185.

48. Vashuk, "Migratsiya ka faktor razvitiya korejskoj diaspory v Primor'e (90-e gg. XX v.)," $175-76$.

49. Kim-Khan, “Aktual'nye problemy korejskoj diaspory v Tsentral'noj Azii,” 183.

50. Interviews with Andrej Kim and Liron Magaj. 


\section{REFERENCES}

Bezugol'ny, Aleksej Y. Narody Kavkaza v Vooruzhennykh silakh SSSR v gody Velikoj Otechestvennoj vojny, 1941-1945 gg. Moscow (forthcoming).

Bugaj, Nikolaj F. L. Beriya-I. Stalinu: “Soglasno Vashemu ykazaniyu....”. Moscow: AIRO XX, 1995.

Korejtsy v Soyuze SSR-Rossii: XX-j vek. Moscow: Insan, 2004.

Dzharylgasinova, Roza Sh. "Osnovnye tendentsii etnicheskikh protsessov u korejtsev Srednej Azii i Kazakhstana.” In Etnicheskie protsessy i natsional'nykh grupp Srednej Azii i Kazakhstana. Moscow: Nauka, 1980.

Kim, German N. Istoriya immigratsii korejtsev 1. Almaty: Dajk-Press, 1999.

Kim, German, and Valerij Khan. "Aktual'nye problemy korejskoj diaspory v Tsentral'noj Azii." Diaspory, no. 2-3 (2001).

Kim, Petr G. Korejtsy Respubliki Uzbekistan (istoriya i sovremennost'). Tashkent: Uzbekiston, 1993.

Kim, Vladimir. Tumangan—pogranichnaya reka. Tashkent: Uzbekiston, 1994.

Oh, Chong J. "Diaspora Nationalism: The Case of the Ethnic Korean Minority in Kazakhstan and its Lessons from the Crimean Tatars in Turkey." Nationalities Papers 34, no. 2 (2006): $111-29$.

Oka, Natsuko. "Korejtsy v sovremennom Kazakhstane: strategiya vyzhivaniya v roli etnicheskogo men'shinstva." Diaspory, no. 2-3 (2001).

Pak, Boris. Potomki strany belykh aistov (kratkaya istoriya sovetskikh korejtsev). Tashkent: Uzbekiston, 1990.

Pobol', Nikolaj L., and Pavel M. Polyan, eds. Stalinskie deportatsii, 1928-1953. Moscow: Materik, 2005.

Polyan, Pavel. Ne po svoej vole ... Istoriya i geografiya prinuditel'nykh migratsii $v$ SSSR. Moscow: OGI-Memorial, 2001.

Rakhmankulova, Adolat Kh. "Ob ispol'zovanii trudovogo potentsiala deportirovannykh narodov v Uzbekistane v kontse 1930-kh-1940-e gody." Etnograficheskoe obozrenie, no. 5 (2006).

Vashuk, Angelina. "Migratsiya ka faktor razvitiya korejskoj diaspory v Primor'e (90-e gg. XX v.)." Diaspory, no. 2-3 (2001).

\section{Primary Sources}

Itogi vsesoyuznoj perepisi naseleniya 1970 goda. Vol. IV, Natsional'nyj sostav naseleniya. Moscow: Tsentral'noe Statisticheskoe Upravlenie SSSR, 1973.

Itogi vsesoyuznoj perepisi naseleniya 1989 goda. Vol. 1 and vol. Natsional'nyj sostav naseleniya. Tashkent: Gosudarstvennyj komitet Respubliki Uzbekistan po statistike, 1990.

Itogi vsesoyuznoj perepisi naseleniya 1989 goda. Vol. IX, Natsional'nyj sostav naseleniya. Moscow: Tsentral'noe Statisticheskoe Upravlenie SSSR, 1991-93.

\section{Archival References}

Gosudarstvennyj Arkhiv Samarkanskoj Oblasti (State Archives of the Samarkand Region).

Fond 7, Otdel narodnogo obrazovaniya ispolkoma Samarkanskogo gorsudarstvennogo soveta.

Fond 74, Samarkandskij oblastnoj Ispolkom.

Fond 913, Upolnomochennyj Narodnogo Komissariata Torgovlii SSSR po snabzheniyu evakuirovannykh polyakov.

Fond 1073, Pereselencheskij otdel Samarkandskogo Oblispolkoma.

Fond 1515, Statisticheskoe Upravlenie Samarsandskoj oblasti. 
Copyright of Nationalities Papers is the property of Routledge and its content may not be copied or emailed to multiple sites or posted to a listserv without the copyright holder's express written permission. However, users may print, download, or email articles for individual use. 
Copyright of Nationalities Papers is the property of Routledge and its content may not be copied or emailed to multiple sites or posted to a listserv without the copyright holder's express written permission. However, users may print, download, or email articles for individual use. 